\title{
Poly-I-lysine-coated magnetic nanoparticles as intracellular actuators for neural guidance
}

This article was published in the following Dove Press journal:

International Journal of Nanomedicine

22 June 2012

Number of times this article has been viewed

\section{Cristina Riggiol,** \\ Maria Pilar Calatayud 2,* \\ Clare Hoskins ${ }^{3}$ \\ Josephine Pinkernelle \\ Beatriz Sanz ${ }^{2}$ \\ Teobaldo Enrique Torres ${ }^{2,5}$ \\ Manuel Ricardo Ibarra ${ }^{2,5}$ \\ Lijun Wang ${ }^{3}$ \\ Gerburg Keilhoff ${ }^{4}$ \\ Gerardo Fabian Goya ${ }^{2,5}$ \\ Vittoria Raffa ${ }^{1,6}$ \\ Alfred Cuschieri ${ }^{1,3}$ \\ 'Institute of Life Science, Scuola Superiore Sant'Anna, Piazza Martiri della Libertà, \\ Pisa, Italy; ${ }^{2}$ Instituto de Nanociencia de \\ Aragón, Universidad de Zaragoza. Mariano \\ Esquillor, Zaragoza, Spain; ${ }^{3}$ MSaT, Institute \\ for Medical Science and Technology, \\ University of Dundee, Dundee, Scotland; \\ ${ }^{4}$ Otto-von-Guericke University, Institute of \\ Biochemistry and Cell Biology, Magdeburg, \\ Germany; ${ }^{5}$ Departamento de Física de la \\ Materia Condensada, Facultad de Ciencias, \\ Universidad de Zaragoza. Cerbuna 12 , \\ Zaragoza, Spain; ${ }^{6}$ Department of Biology, \\ Università di Pisa, Pisa, Italy \\ *These authors contributed equally to this work}

Correspondence: Vittoria Raffa Institute of Life Science, Scuola Superiore Sant'Anna, Piazza Martiri della Libertà, 33 56/27, Pisa, Italy

Tel +3950995 625

Fax +3950995 676

Emailv.raffa@sssup.it

or

Gerardo F Goya

Instituto de Nanociencia de Aragón

(INA), Universidad de Zaragoza,

Campus Rio Ebro - CP 50018 ,

Zaragoza, Spain

Tel +34976765362

Fax +34976765362

Email goya@unizar.es
Purpose: It has been proposed in the literature that $\mathrm{Fe}_{3} \mathrm{O}_{4}$ magnetic nanoparticles (MNPs) could be exploited to enhance or accelerate nerve regeneration and to provide guidance for regenerating axons. MNPs could create mechanical tension that stimulates the growth and elongation of axons. Particles suitable for this purpose should possess (1) high saturation magnetization, (2) a negligible cytotoxic profile, and (3) a high capacity to magnetize mammalian cells. Unfortunately, the materials currently available on the market do not satisfy these criteria; therefore, this work attempts to overcome these deficiencies.

Methods: Magnetite particles were synthesized by an oxidative hydrolysis method and characterized based on their external morphology and size distribution (high-resolution transmission electron microscopy [HR-TEM]) as well as their colloidal ( $\mathrm{Z}$ potential) and magnetic properties (Superconducting QUantum Interference Devices [SQUID]). Cell viability was assessed via Trypan blue dye exclusion assay, cell doubling time, and MTT cell proliferation assay and reactive oxygen species production. Particle uptake was monitored via Prussian blue staining, intracellular iron content quantification via a ferrozine-based assay, and direct visualization by dual-beam (focused ion beam/scanning electron microscopy [FIB/SEM]) analysis. Experiments were performed on human neuroblastoma SH-SY5Y cell line and primary Schwann cell cultures of the peripheral nervous system.

Results: This paper reports on the synthesis and characterization of polymer-coated magnetic $\mathrm{Fe}_{3} \mathrm{O}_{4}$ nanoparticles with an average diameter of $73 \pm 6 \mathrm{~nm}$ that are designed as magnetic actuators for neural guidance. The cells were able to incorporate quantities of iron up to $2 \mathrm{pg} / \mathrm{cell}$. The intracellular distribution of MNPs obtained by optical and electronic microscopy showed large structures of MNPs crossing the cell membrane into the cytoplasm, thus rendering them suitable for magnetic manipulation by external magnetic fields. Specifically, migration experiments under external magnetic fields confirmed that these MNPs can effectively actuate the cells, thus inducing measurable migration towards predefined directions more effectively than commercial nanoparticles (fluidMAG-ARA supplied by Chemicell). There were no observable toxic effects from MNPs on cell viability for working concentrations of $10 \mu \mathrm{g} / \mathrm{mL}\left(\mathrm{EC}_{25}\right.$ of $20.8 \mu \mathrm{g} / \mathrm{mL}$, compared to $12 \mu \mathrm{g}$ / $\mathrm{mL}$ in fluidMAG-ARA). Cell proliferation assays performed with primary cell cultures of the peripheral nervous system confirmed moderate cytotoxicity $\left(\mathrm{EC}_{25}\right.$ of $\left.10.35 \mu \mathrm{g} / \mathrm{mL}\right)$.

Conclusion: These results indicate that loading neural cells with the proposed MNPs is likely to be an effective strategy for promoting non-invasive neural regeneration through cell magnetic actuation.

Keywords: magnetic nanoparticle, actuator, migration, neural regeneration

\section{Introduction}

The direct impact of magnetic nanoparticles (MNPs) for biomedical applications has increased significantly over the last decade. ${ }^{1}$ Many diagnostic tools currently use MNPs 
for purposes such as contrast agents in magnetic resonance imaging or magnetic vectors for drug delivery. ${ }^{2}$ Magnetite $\left(\mathrm{Fe}_{3} \mathrm{O}_{4}\right)$ and maghemite $\left(-\gamma-\mathrm{Fe}_{2} \mathrm{O}_{3}\right)$ ferrimagnetic materials are the most commonly used in biomedicine for their high saturation magnetization $\mathrm{M}_{\mathrm{S}}\left(85-95 \mathrm{Am}^{2} / \mathrm{kg}\right)$, biological compatibility, environmental stability, and low synthesis costs. The physical principles behind the most common applications of $\mathrm{MNPs}^{3}$ are (a) the capacity to remotely guide MNPs by external magnetic fields; (b) heat generation from the MNPs in a magnetic colloid when submitted to alternating magnetic fields, and (c) a large magnetic moment of singledomain MNPs as a disturbance of proton nuclear resonance. In bioengineering MNPs for a specific application, the reactive surface of MNPs can be functionalized with biocompatible coatings. ${ }^{4-7}$ The addition of bioactive molecules, such as adding targeting-moieties to the MNP surface, is employed to increase their specificity toward cellular targets, thus preventing their interaction with healthy tissue. ${ }^{8-10}$

In recent years, cell labeling with MNPs has become a widely used method for several in vitro ${ }^{11}$ and in vivo ${ }^{1-3}$ applications, ranging from cell sorting to magnetic resonance imaging (MRI) tracking. ${ }^{13}$ Furthermore, MNP-labeled cells that are transplanted in living rats can be manipulated in order to alter biodistribution and enable their accumulation in the intended target organ. ${ }^{14}$ The retention of magnetic responsive cells can be enhanced using an external magnetic field produced by a magnet ${ }^{15}$ that is focused on the area of interest.

This study represents the first step in the exploitation of MNPs to enhance nerve regeneration in injured nerves. In this regenerative process, the physical guidance of axons is a vital component of nerve repair, which together with biochemical signals, is critical for effective nerve regeneration. MNPs, by virtue of their ability to interact with living cells, create a mechanical tension that stimulates the growth and elongation of axons under the influence of external magnetic fields. ${ }^{16}$ This combination of physical guidance and targeted drug transport underlies the potential role of MNPs in the development of novel, minimally invasive therapies for nerve regeneration. The challenge lies in the development of effective protocols. The MNPs necessary for the realization of this therapeutic intent should possess tailored features such as small size, capacity for surface functionalization, minimal cytotoxicity, stability, high magnetic response, and ability to magnetize cellular structures stably.

The initial stage of this ongoing study entailed the production and characterization of novel iron oxide nanoparticles with superior properties. The second step was to demonstrate that the synthesized MNPs exhibited higher saturation magnetization, biocompatibility, and the capacity to label mammalian cells magnetically and more effectively than the best commercially available MNPs. The experiments were carried out on human neuroblastoma cell line and primary Schwann cell cultures of the nervous system. The third phase of the work investigates the effects of the particles on cell physiology, including the cell proliferation rate, reactive oxygen species (ROS) production, and their intracellular localization.

\section{Materials and methods Synthesis of PLL- $\mathrm{Fe}_{3} \mathrm{O}_{4}$ nanoparticles}

Magnetite particles were synthesized by an oxidative hydrolysis method. ${ }^{17}$ A mixture of $1.364 \mathrm{~g}$ of $\mathrm{KNO}_{3}$ (99\%; Acros Organics, Geel, Belgium) and $0.486 \mathrm{~g}$ of $\mathrm{NaOH}$ (Electron Microscopy Sciences, Hatfield, PA) was dissolved in $135 \mathrm{~mL}$ of distilled water in a three-necked flask and bubbled with $\mathrm{N}_{2}$. Next, $15 \mathrm{~mL}$ of $0.01 \mathrm{M} \mathrm{H}_{2} \mathrm{SO}_{4}$ (96\%; Panreac, Barcelona, Spain) solution containing 0.308 g of $\mathrm{FeSO}_{4} 7 \mathrm{H}_{2} \mathrm{O}(\geq 99 \%$; Sigma-Aldrich, St Louis, MO) that was previously flowed with $\mathrm{N}_{2}$ for 2 hours was added drop-wise under constant stirring. After precipitation was completed, an additional 5 minutes of $\mathrm{N}_{2}$ flow was allowed to pass and the system was heated to $90^{\circ} \mathrm{C}$ for 24 hours. Finally, the solution was cooled to room temperature with an ice bath. The resulting black product was separated by magnetic decantation and washed several times with distilled water to remove all remaining impurities after the synthesis. These samples will be referred to as "naked-MNPs" hereafter.

To obtain nanoparticles coated with poly-l-lysine (PLL), the former naked-MNPs were re-suspended in a solution of PLL 0.1\% ( $\leq 150 \mathrm{kD}$; Sigma-Aldrich) and sonicated overnight (Dambury, CT). The solution was then washed several times in order to remove the excess of PLL and resuspended in water. This sample will be referred to as "PLL-MNP" hereafter.

The commercial MNPs used in this work (fluidMAGARA; Chemicell GmbH, Berlin, Germany) are composed of a maghemite core coated with a glucuronic acid layer on the surface. For comparison purposes, these particles were functionalized with PLL by activating the surface of the functional groups. The polymer matrix of these particles has functional carboxylic groups that were used for covalent binding with the amino groups of the PLL. In addition, $0.6 \mathrm{mg}$ of 1-Ethyl-3-(3-dimethylaminopropyl) carbodiimide hydrochloride (EDAC) and $1.2 \mathrm{mg}$ of N-hydroxysuccinimide were added to $1 \mathrm{mg} / \mathrm{mL}$ of MNP colloid. After the activation of the carboxylic group particles 
were resuspended in a solution of $0.1 \mathrm{mg} / \mathrm{mL}$ of PLL and after 3 hours of continuous mixing at room temperature, the carboxylic group particles were washed several times in order to remove the excess of PLL and resuspended in water. The resulting PLL-coated nanoparticles will be referred to as "ARA-MNPs" hereafter.

The PLL-MNPs and ARA-MNPs had the same hydrodynamic radius (approximately $200 \mathrm{~nm}$ ), while the average magnetic core was $<\mathrm{d}>=73 \pm 6$ and $10 \mathrm{~nm}$ for PLL-MNPs and ARA-MNPs, respectively.

\section{Determination of $\mathrm{Fe}_{3} \mathrm{O}_{4}-\mathrm{MNPs}$ content in the magnetic colloids}

The $\mathrm{Fe}_{3} \mathrm{O}_{4}$ concentration of each colloid was measured through UV spectrophotometry after completing the dissolution of the MNPs in acid media. Ferrous ions present in the solution were oxidized to ferric ions by $\mathrm{HNO}_{3}$ prior to reacting with thiocyanate salt to form the iron-thiocyanate complex $\left(\left[\mathrm{Fe}(\mathrm{SCN})_{6}\right]^{3-}{ }_{(\text {aq })}\right)$. PLL-MNPs were completely dissolved in $1: 1 \mathrm{v} / \mathrm{v} \mathrm{HCl} 6 \mathrm{M}-\mathrm{HNO}_{3}(65 \%)$ for 2 hours at elevated temperatures $\left(50^{\circ} \mathrm{C}-60^{\circ} \mathrm{C}\right)$. Potassium thiocyanate was added to the $\mathrm{Fe}^{3+}$ solution and then the iron concentration was determined by spectrophotometric measurements at $478 \mathrm{~nm}$ using a CARY-50 Probe UV-visible recording spectrophotometer (Varian Company, Palo Alto, CA).

\section{Characterization of $\mathrm{Fe}_{3} \mathrm{O}_{4}$ nanoparticles}

Naked-MNPs and PLL-MNPs were characterized based on their external morphology, size distribution, colloidal, and magnetic properties.

\section{Transmission electron microscopy}

The MNPs' average size, distribution, and morphology were studied by transmission electron microscopy (TEM) using a FEI Tecnai T20 microscope (FEI Company, Eindhoven, The Netherlands) operating at an acceleration voltage of $200 \mathrm{KV}$. High resolution transmission electron microscopic images were obtained using a FEI Tecnai F30 microscope operated at an acceleration voltage of $300 \mathrm{KV}$. Samples were prepared by placing one drop of a dilute suspension of magnetite nanoparticles in water on a carbon-coated copper grid and allowing the solvents to evaporate at room temperature. The average particle size and distribution were evaluated by measuring 200 particles.

\section{Zeta potential}

The zeta potential was evaluated at room temperature on a photo correlation spectrometer (PCS) Brookhaven
90 plus (Zetasizer Nano ${ }^{\mathrm{TM}}$; Malvern Instruments, Worcestershire, UK) from a dilute suspension of the sample in water at $0.01 \mathrm{M}$ of $\mathrm{KCl}$.

\section{Magnetic characterization}

The magnetic characterization of the samples was carried out in a Superconducting QUantum Interference Device (SQUID), model MPMS-XL (Quantum Design, Inc., San Diego, CA). Zero-field-cooled (ZFC) and field-cooled (FC) curves were measured between $10 \mathrm{~K}$ and $250 \mathrm{~K}$, with cooling field $\mathrm{H}_{\mathrm{FC}}=100 \mathrm{Oe}$. For the $\mathrm{ZFC}$ curves, the samples were first cooled to the basal temperature $(10 \mathrm{~K})$ without applied field. Next, a field was applied and the variation of magnetization was measured by increasing the temperature up to $\mathrm{T}=250 \mathrm{~K}$. After the last point was measured, the FC curve was taken by cooling the sample and keeping the same field; then, the $M$ versus $T$ data was measured for increasing temperatures. Low-temperature hysteresis loops $(10-250 \mathrm{~K})$ were obtained in the applied fields up to $5 \mathrm{~T}$.

\section{Cell line}

Human neuroblastoma SH-SY5Y cells (ATCC CRL-2266) were cultured in Dulbecco's Modified Eagle's Medium (DMEM; Lonza, Verviers, Belgium) and Ham's F12 (1:1) (Lonza) with $10 \%$ fetal bovine serum, $100 \mathrm{IU} / \mathrm{mL}$ penicillin, $100 \mu \mathrm{g} / \mathrm{mL}$ streptomycin, and $2 \mathrm{mM}$ L-glutamine. The cells were maintained at $37^{\circ} \mathrm{C}$ in a saturated humidity atmosphere containing $95 \%$ air and $5 \% \mathrm{CO}_{2}$.

\section{Cell viability}

Cells in the exponential growth phase were seeded into a sixwell plate and incubated for 24 hours at $37^{\circ} \mathrm{C}$ with $5 \% \mathrm{CO}_{2}$. Different concentrations of MNPs $(0-100 \mu \mathrm{g} / \mathrm{mL})$ were added to the cell medium. After incubation (1-7 days) the medium was removed and the cells were washed with PBS. The cells were detached using trypsin and resuspended in $1 \mathrm{~mL}$ of fresh media. Trypan blue was added to $100 \mu \mathrm{L}$ in equal volume and incubated at room temperature for 5 minutes. The viable cells were counted using a hemocytometer and the number of cells per well was deduced. The percentage of cell viability with respect to the control well was calculated by assuming the control well had $100 \%$ viability.

To evaluate the effect of PLL-MNPs on the growth rate, 50,000 cells were seeded in a six-well plate. After 24 hours, 48 hours, and 72 hours, the cells were detached by trypsinization and counted with a Burker's chamber. The doubling time $T_{d}$ was calculated using the following formula: $T_{d}=T_{2}-T_{1}$ 
$\ln (2) / \ln \left(\mathrm{q}_{2}-\mathrm{q}_{0}\right)$ where $\mathrm{q}_{0}$ is the number of cells at time $\mathrm{T}_{0}$ and $\mathrm{q}_{2}$ represents the number of cells at time $\mathrm{T}_{2}$.

\section{Detection of ROS}

The production of ROS in cells treated with PLL-MNPs was investigated using the Image-IT Green Reactive Oxygen Species Detection kit (Invitrogen, Eugene, OR). Cells $(250,000$ per well) were seeded in a six-well plate and incubated with an increasing concentration of PLL-MNPs $(1-50 \mu \mathrm{g} / \mathrm{mL}$ ) for 24 hours. As a positive control, the cells were incubated for 2 hours with tert-butyl hydroperoxide (TBHP), a common inducer of ROS. ${ }^{18}$ The negative control was performed on cells cultured in a normal growth medium. Thereafter, all the samples were incubated for 30 minutes with a $25 \mu \mathrm{M}$ carboxy- $\mathrm{H}_{2}$ DCFDA and immediately observed via fluorescence microscopy with the appropriate filters.

\section{Prussian blue staining}

The amount of intracellular iron was determined by a Fe (II,III)hexacyanoferrate staining (Prussian blue) reaction in which ionic iron reacts with acid ferrocyanide to produce a blue color. The Prussian blue staining procedure was carried out according to the supplier's instructions. The PLL-MNPs cells were fixed with methanol after the cells were seeded in a six-well plate, after 24 hours of incubation, and after the staining was fixed. The iron blue pigment was revealed under light microscopy.

\section{Quantification of internal iron per cell}

The amount of iron inside the cells was investigated using a colorimetric ferrozine-based assay (Sigma-Aldrich) after 24 hours, 48 hours, and 72 hours. ${ }^{19}$ The cells were seeded $(50,000)$ in six-well dishes and 24 hours after they were treated with PLL-MNPs $(1-50 \mu \mathrm{g} / \mathrm{mL})$. The cells were washed twice with $2 \mathrm{~mL}$ of ice cold phosphate-buffered saline (PBS) containing deferoxamine in a final concentration of $1 \mathrm{mM}$. The deferoxamine, an iron chelator, was used to exclude the iron that was non-specifically attached to the cell membranes rather than taken up into the cells. The cells were lysed with $200 \mu 1$ of $\mathrm{NaOH}$ for 2 hours in a humidified atmosphere. The cell lysate was added to $100 \mu 1$ of $\mathrm{HCl}$ $(10 \mathrm{mM})$ and $100 \mu \mathrm{l}$ of a water solution with equal volumes of $\mathrm{HCl}(1.4 \mathrm{M})$ and $\mathrm{KMnO}_{4}(4.5 \% \mathrm{w} / \mathrm{v})$. The cell lysate was then allowed to incubate for 2 hours at $60^{\circ} \mathrm{C}$.

After the mixture was cooled at room temperature, $30 \mu 1$ of the iron detection reagent - a water solution composed of 6.5 mM ferrozine (Sigma-Aldrich), $6.5 \mathrm{mM}$ neucoproine (Sigma-Aldrich), 2.5 M ammonium acetate (Sigma-Aldrich), and $1 \mathrm{M}$ ascorbic acid (Sigma-Aldrich) - was added. After
30 minutes, $280 \mu \mathrm{l}$ of solution was transferred into a 96-well dish and the absorbance was measured at $550 \mathrm{~nm}$ on a microplate reader. The iron content was calculated by measuring the sample absorbance (calibration curve obtained using a standard concentration of $\mathrm{FeCl}_{3}$ ).

\section{Dual-beam (FIB/SEM) analysis of intracellular MNPs distribution}

Scanning electron microscopy (SEM) images and energydispersive $\mathrm{x}$-ray spectroscopy (EDX) maps were acquired using an SEM Inspect ${ }^{\mathrm{TM}}$ F50 with an EDX system INCA PentaFETx3 (FEI Company, Eindhoven, The Netherlands) in an energy range between $0-30 \mathrm{keV}$. The intracellular distribution of PEI-MNPs was assessed using dual-beam focused ion beam (FIB)/SEM equipment (Nova200 NanoLab; FEI Company, Eindhoven, The Netherlands) equipped with a $30 \mathrm{kV}$ field emission gun column and a Ga-based $30 \mathrm{kV}$ ion column. Several slices were obtained using the Ga-ion column to produce cross-sections of adherent SH-SY5Y cells, pictures of the cross sections were taken in SEM mode, and the elementary content was analyzed by EDX.

The preparation of the samples was made by seeding SH-SY5Y cells on a sterile glass cover slip at a density of $5 \times 10^{4}$ cells/well in $1.5 \mathrm{~mL}$ of DMEM for 24 hours, after which the growth medium was removed and replaced with the medium containing $5 \mu \mathrm{g} / \mathrm{mL}$ of PLL-MNPs. The cells were fixed with $2 \%$ glutaraldehyde solution for 2 hours. The samples were dehydrated at room temperature via immersion in increasing concentrations of methanol 30\% (x2), 50\% (x2), $70 \%$ (x2), and $90 \%$ (x2) followed by further dehydration with anhydrous $\mathrm{MeOH}$. Finally, the samples were coated with a $30 \mathrm{~nm}$-gold film before they were examined with the SEM and dual-beam techniques.

\section{Primary cells}

Primary Schwann cell cultures were prepared from neonatal rats of postnatal day $5-8$. The cells were mechanically

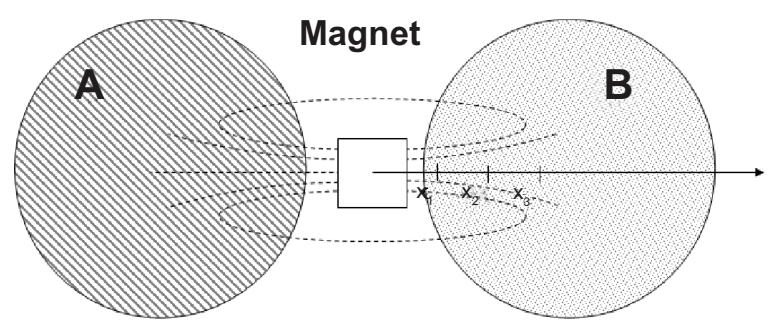

Figure I Experimental set-up for cell migration assay. Cell cultures were incubated with MNP-modified medium (A) and MNP-free medium (B).

Abbreviation: MNP, magnetic nanoparticle. 
A

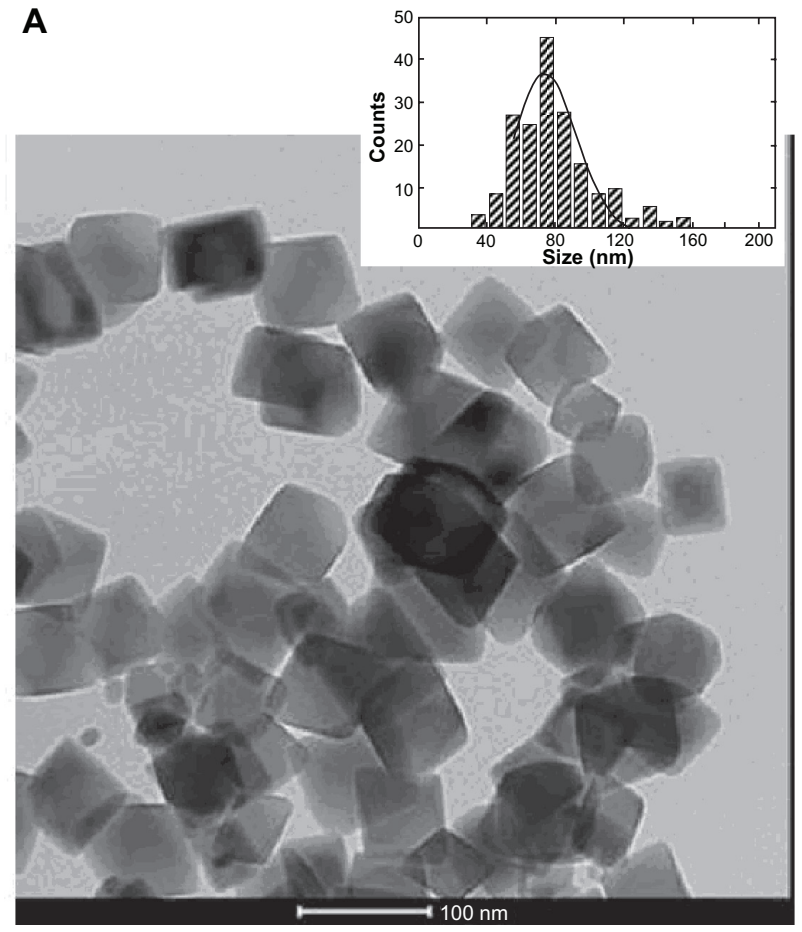

B

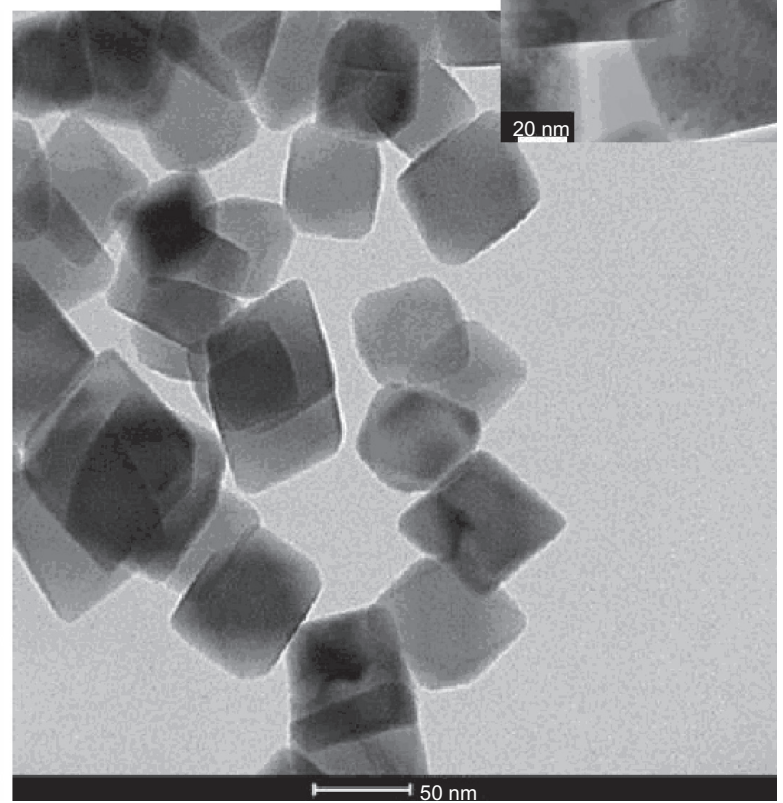

Figure 2 Cell cultures were incubated with MNP-modified medium (A) and MNP-free medium (B). (A) TEM image of naked Fe $\mathrm{O}_{4}$ nanoparticles. Inset: histogram showing the particle size distribution. (B) TEM image of PLL-coated nanoparticles. Inset: high resolution magnification of a single PLL-coated Fe $\mathrm{O}_{4} \mathrm{MNP}$

Abbreviations: MNP, magnetic nanoparticle; PLL, poly-I-lysine; TEM, transmission electron microscopy.

dissociated, centrifuged for 5 minutes at $1500 \mathrm{rpm}$, and resuspended in DMEM containing 10\% fetal calf serum, $6 \mathrm{~g} / \mathrm{L}$ D-glucose, and 1\% Streptomycin/Penicillin. They were then seeded on $35 \mathrm{~mm}$ Petri-dishes with a cell number of $2.5 \times 10^{5}$ cells per Petri dish. The cells were incubated in a humidified $37^{\circ} \mathrm{C}$ and $6 \% \mathrm{CO}_{2}$ atmosphere.

The medium was changed on the first day in vitro (DIV 1) to remove cell debris. On DIV 6, the medium was changed to a medium supplemented with $0,5,10$, or $50 \mu \mathrm{g} / \mathrm{mL}$ of PLL-MNPs. After 24 hours of incubation, the cells were used for viability assay (MTS-assay, CellTiter 96 Aqueous one solution cell proliferation assay; Promega, Madison, WI) or for nuclear fast red aluminum sulphate and Prussian blue staining.

For cell viability, the cells were washed once with sterile PBS. The MTS reagent was added according to the manufacturer and the cells were incubated for 3 hours. The supernatant was, thus, collected and centrifuged $(6000 \mathrm{rpm})$ in order to remove particles that interfere with the absorbance reading. The MNP-free supernatants were, thus, aliquoted in a 96-well plate (one column for each sample) and absorbance was measured with a Tecan M200 microplate reader (Tecan, Männedorf, Switzerland) at $490 \mathrm{~nm}$ wavelength. The values were normalized by the mean of the blank. The percentage of cell viability with respect to the control well was calculated by assuming the control well had $100 \%$ viability.

The cells were stained with nuclear fast red-aluminum sulphate and Prussian blue to check for the integrity of the cell cultures. The cells were fixed for 30 minutes with $4 \%$ paraformaldehyde, washed three times with distilled water, and incubated for 30 minutes at $37^{\circ} \mathrm{C}$ with Prussian blue ( $1 \%$ potassium hexacyanoferrat (II) and $0.5 \%$ hydrochloric acid). Next, the cells were washed again and stained for 5 minutes

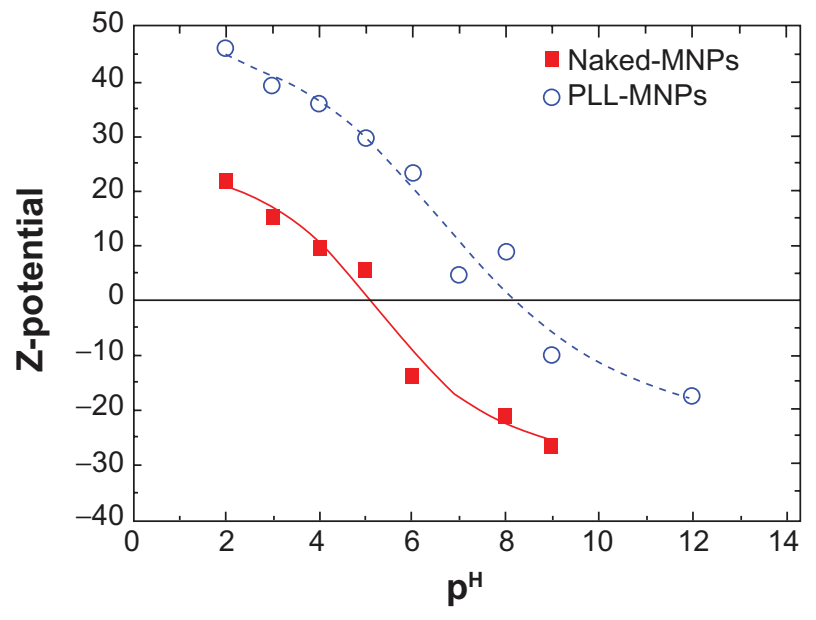

Figure 3 Zeta potential curves as a function of the $\mathrm{pH}$ for naked $\mathrm{Fe}_{3} \mathrm{O}_{4}$ nanoparticles (filled squares) and PLL-coated $\mathrm{Fe}_{3} \mathrm{O}_{4}$ nanoparticles (open circles).

Note: The lines are a guide for the eye.

Abbreviations: MNPs, magnetic nanoparticles; PLL, poly-I-lysine. 
A

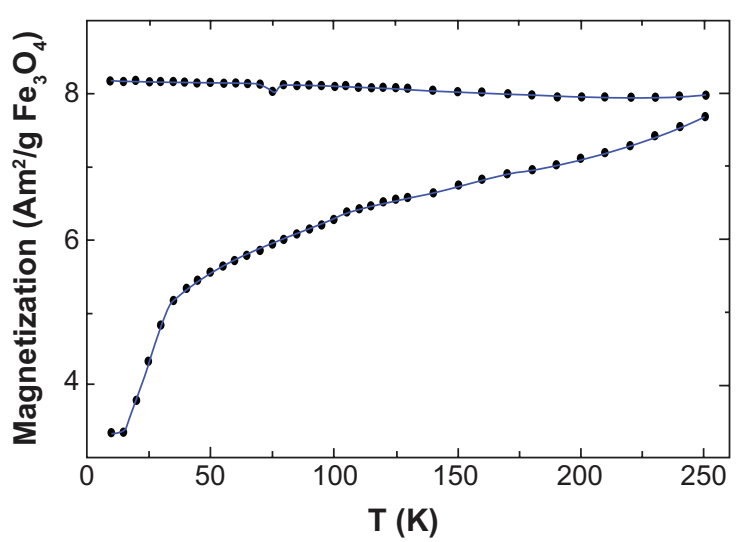

B

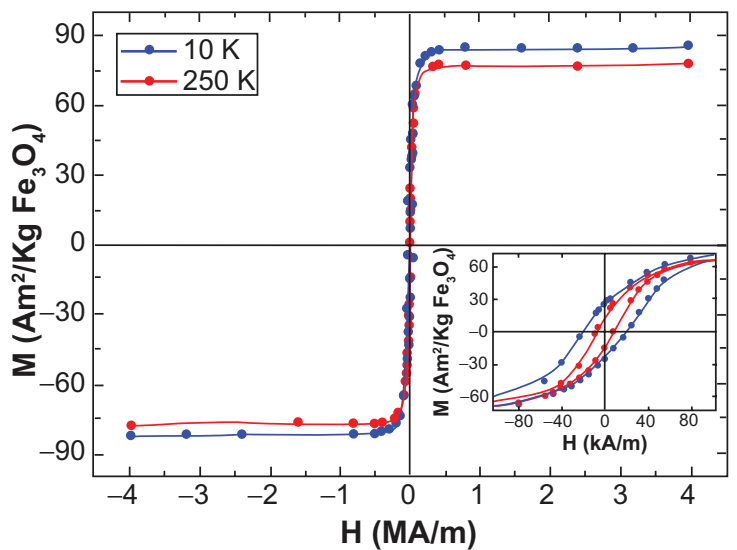

Figure 4 Magnetization data of PLL-coated $\mathrm{Fe}_{3} \mathrm{O}_{4}$ nanoparticles. (A) $\mathrm{M}(\mathrm{T})$ curves taken in zero-field and field-cooling modes using $\mathrm{H}_{\mathrm{FC}}=7.97 \mathrm{kA} / \mathrm{m}$. (B) $\mathrm{M}(\mathrm{H})$ magnetization curves at $10 \mathrm{~K}$ and $250 \mathrm{~K}$.

Note: The inset shows a magnification of the low-field $M(H)$ curves to better see the coercivity of the MNPs.

Abbreviations: MNPs, magnetic nanoparticles; PLL, poly-I-lysine.

with nuclear fast red solution (N3020; Sigma-Aldrich), washed, and embedded for microscopy. Images were taken with an AxioImager microscope (Zeiss, Jena, Germany).

\section{Cell migration assay}

Cell migration assay was performed on the cell line and primary Schwann cell cultures. SH-SY5Y cells were seeded with 100,000 cells per well in two wells of a six-well plate. Primary cell cultures were prepared as described above and seeded with 500,000 cells per well in two laminin-coated wells of a six-well plate. After 1 or 2 days of adhesion for the cell line and primary cells, respectively, the medium modified with the particles (10 $\mu \mathrm{g} / \mathrm{mL}$ of ARA-MNP or $10 \mu \mathrm{g} / \mathrm{mL}$ of PLL-MNP) and normal medium were added to the sample and the control, respectively. After 24 hours of incubation, a neodymium cubic magnet (N48, Residual Induction $1.41 \mathrm{~T}$, cube side $12 \mathrm{~mm}$ ) was placed between the two wells (Figure 1). After 72 hours, the local cell density, $c,\left(\right.$ cell $/ \mathrm{mm}^{2}$, ie, cells counted in a square of $\left.0.24 \mathrm{~mm}^{2}\right)$ was measured at three defined points $\mathrm{x}_{1}, \mathrm{x}_{2}$, and $\mathrm{x}_{3}$ (distance from the magnet $5 \mathrm{~mm}, 10 \mathrm{~mm}$, and $15 \mathrm{~mm}$, respectively). The cells were then detached and counted. The average cell density, $c_{0}$, (cell $/ \mathrm{mm}^{2}$, ie, the cells counted in the Petri dish, size $960 \mathrm{~mm}^{2}$ ) was evaluated. All the data were normalized with respect to $c_{0}$ in order to make them comparable.

\section{Results}

\section{Synthesis of PLL-coated $\mathrm{Fe}_{3} \mathrm{O}_{4}$ nanoparticles}

Electron transmission microscopy showed that the morphology of magnetic cores in both the naked- and PLL-MNPs were of octahedral morphology with an average size $\mathrm{d}=73 \pm 6 \mathrm{~nm}$ (Figure 2). The colloidal suspensions of these MNPs were not stable at $\mathrm{pH} 7$ due to their large particle size. However, redispersion and manipulation of the precipitate using magnetic fields was easily achieved.

The variation in the surface electrostatic potential was characterized by a Z-potential measurement (Figure 3). As can be seen, there is obvious difference in the isoelectric point between the naked-MNPs and the PLL-MNPs, which measured 5.1 and 8.2 respectively.

The $\mathrm{Z}$ potential of the samples was evaluated as a function of $\mathrm{pH}$ to evaluate the surface charge and isoelectric point of the resulting MNPs. It was found that the Z-potential at physiological $\mathrm{pH}=7$ was negative $(-20 \mathrm{mV})$ for nakedMNPs and positive $(+10 \mathrm{mV})$ for PLL-MNPs. The higher positive charge values of the PLL-NPs - when compared to naked-MNPs at low and neutral $\mathrm{pH}$ - and the shift of the isoelectric point are both due to the presence of the PLL amino

Table I Average diameter $<\mathbf{d}>$ of the magnetite core; saturation magnetization $M_{s}$, and coercive field $H_{c}$ of the magnetic nanoparticles used in this work

\begin{tabular}{|c|c|c|c|c|c|}
\hline \multirow[t]{2}{*}{ Sample } & \multirow[t]{2}{*}{$<\mathbf{d}>(\mathbf{n m})$} & \multicolumn{2}{|l|}{$250 \mathrm{~K}$} & \multicolumn{2}{|l|}{$10 \mathrm{~K}$} \\
\hline & & $\begin{array}{l}M_{s} \\
\left(\mathrm{Am}^{2} / \mathrm{kg}\right)\end{array}$ & $\begin{array}{l}\mathrm{H}_{\mathrm{c}} \\
(\mathrm{kA} / \mathrm{m})\end{array}$ & $\begin{array}{l}M_{s} \\
\left(\mathrm{Am}^{2} / \mathrm{kg}\right)\end{array}$ & $\begin{array}{l}\mathrm{H}_{\mathrm{c}} \\
(\mathrm{kA} / \mathrm{m})\end{array}$ \\
\hline PLL-MNPs & $73 \pm 6$ & 78 & 8.1 & 85 & 19.9 \\
\hline Naked-MNPs & $73 \pm 6$ & 77 & 9.7 & 84 & 20.3 \\
\hline ARA-MNPs* & 10 & 49 & 0.1 & 53 & 0.8 \\
\hline
\end{tabular}

Note: *Commercial fluidMAG-ARA (Chemicell GmbH, Berlin, Germany) nanoparticles.

Abbreviations: MNPs, magnetic nanoparticles; ARA-MNPs, commercial fluidMAGARA magnetic nanoparticles; PLL, poly-l-lysine; d, average diameter; MS, saturation magnetization; $\mathrm{HC}$, coercive field. 


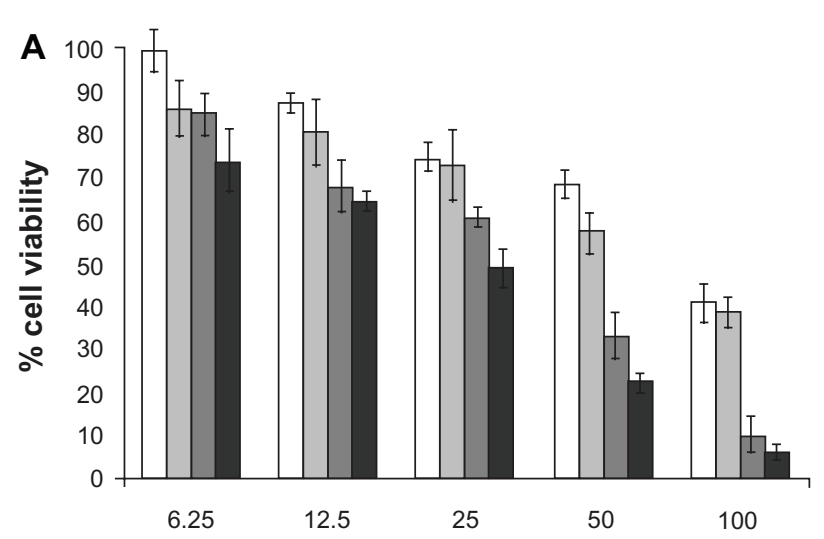

PLL-MNP concentration $(\mu \mathrm{g} / \mathrm{mL})$

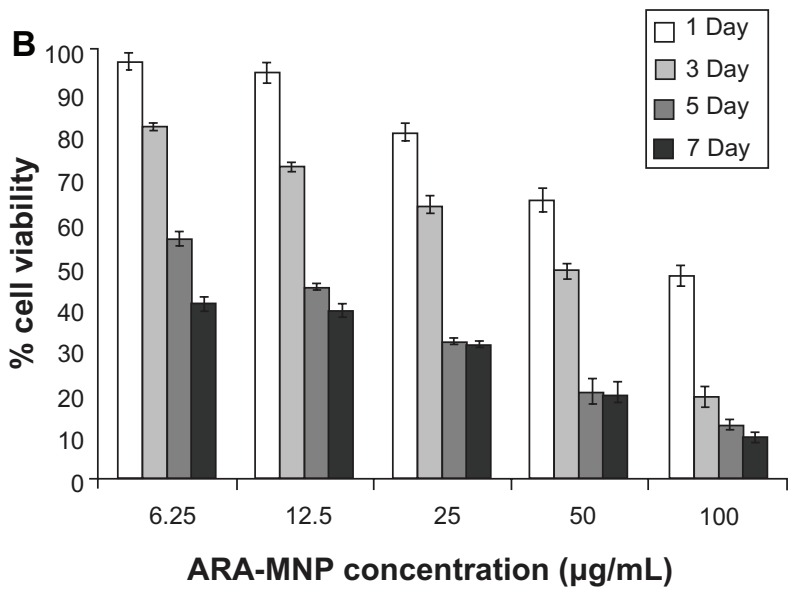

ARA-MNP concentration $(\mu \mathrm{g} / \mathrm{mL})$

Figure 5 Cell viability of SH-SY5Y cells from trypan blue staining, for increasing MNP concentration and incubation time using PLL-MNPs (A) and ARA-MNPs (B). Abbreviations: ARA-MNPs, commercial fluidMAG-ARA magnetic nanoparticles; PLL-MNPs, poly-l-lysine-magnetic nanoparticles.

A

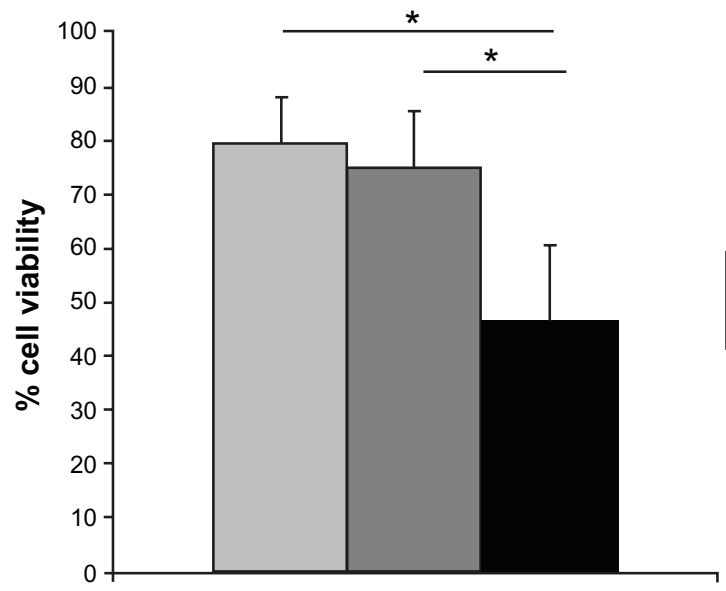

B

$\square 5 \mu \mathrm{g} / \mathrm{mL}$ PLL-MNPs 口 $10 \mu \mathrm{g} / \mathrm{mL}$ PLL-MNPs $50 \mu \mathrm{g} / \mathrm{mL}$ PLL-MNPs

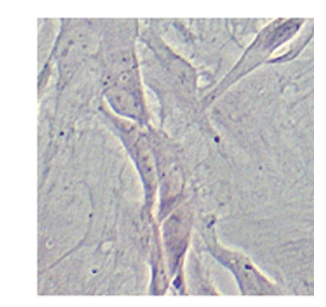

$10 \mu \mathrm{g} / \mathrm{mL}$ PLL-MNPs

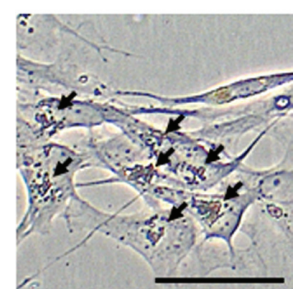

Figure 6 Primary Schwann cell cultures from the peripheral nervous system: (A) cell viability; (B) nuclear fast red and Prussian blue staining. Notes: One-way ANOVA with Bonferroni post hoc test, $* P<0.001$. Bar indicates $50 \mu \mathrm{m}$.

Abbreviation: PLL-MNPs, poly-I-lysine-magnetic nanoparticles.

A

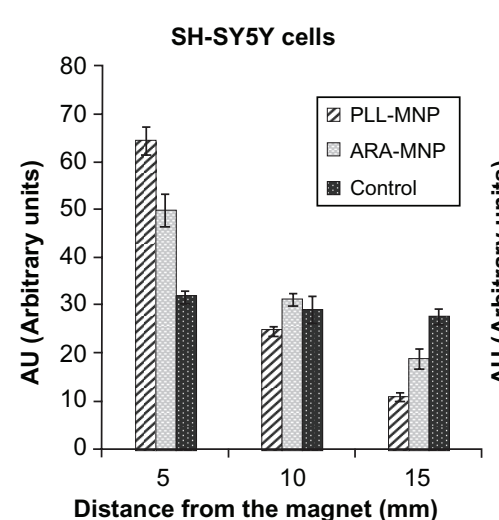

B

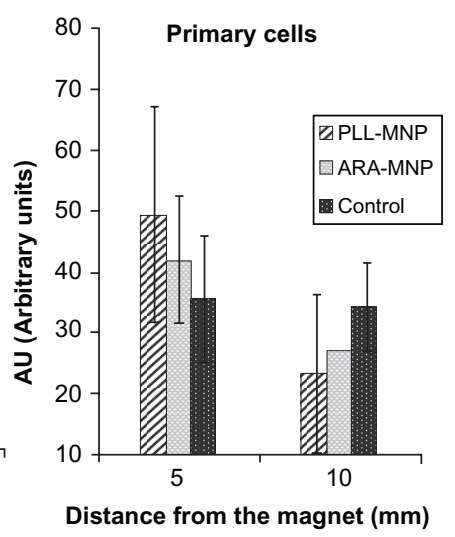

C

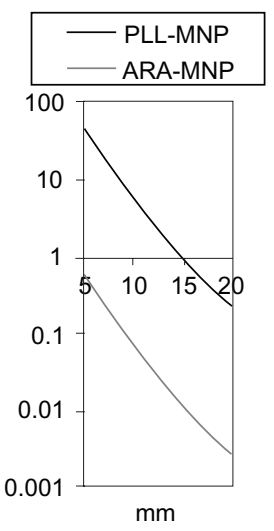

Figure 7 PLL-MNPs compared with ARA-MNP. Cell density (in arbitrary units) at different distances from the magnet for (A) SH-SY5Y cells and (B) primary cells. Control represents cells not treated with magnetic particles $(n=3)$. (C) Comparison of the magnetic force exerted by PLL-MNP and ARA-MNP as a function of the distance from the magnet.

Abbreviations: ARA-MNPs, commercial fluidMAG-ARA magnetic nanoparticles; PLL-MNPs, poly-l-lysine-magnetic nanoparticles. 
Table 2 Effect of the concentration of incubated PLL-MNPs on SH-SY5Y cell doubling time

\begin{tabular}{|c|c|c|c|c|}
\hline & \multicolumn{4}{|c|}{ PLL-MNP concentration ( $\mu \mathrm{g} / \mathrm{mL})$} \\
\hline & 0 & 10 & 20 & 50 \\
\hline $\begin{array}{l}\text { Cell doubling } \\
\text { time (hours) }\end{array}$ & $23.94 \pm 1.16$ & $23.93 \pm 0.11$ & $27.97 \pm 0.20 *$ & $4 I .01 \pm 0.75^{* *}$ \\
\hline
\end{tabular}

groups, which confirms the successful functionalization of the MNPs surface.

The magnetization measurements of naked- and PLLMNPs showed similar results, as both samples are formed from the same magnetic cores. The ZFC-FC curves showed the typical features of single domain MNPs such as irreversible behavior below room temperature. The increase in the ZFC curves with increasing temperature indicates that the blocking temperature of these particles is above room temperature, which is in agreement with their large size. The coercivity, $\mathrm{H}_{\mathrm{C}}$, and saturation magnetization, $M_{S}$, values extracted from the $M(H)$ curves at $T=10 \mathrm{~K}$ and $250 \mathrm{~K}$ are consistent with the highly crystalline $\mathrm{Fe}_{3} \mathrm{O}_{4}$ MNPs that were already blocked at room temperature (Figure 4).

\section{Comparison between PLL-coated and commercial $\mathrm{Fe}_{3} \mathrm{O}_{4}$ MNPs}

This section compares the physical (Table 1), chemical, and biological properties of the homemade nanoparticles with commercial particles. The commercial ARA-MNPs particles selected for this purpose were previously studied for labeling and heating purposes..$^{20}$ ARA-MNPs showed a larger hydrodynamic radius due to the presence of a polymeric matrix on the magnetic core and lower magnetic properties in terms of magnetization saturation and coercivity.

The biocompatibility of PLL-MNPs and ARA-MNPs were evaluated by dose-response experiments to obtain the effective concentration of MNPs that reduces cell viability by $25 \%\left(\mathrm{EC}_{25}\right)$.

Experimental results showed that the cytotoxicity induced by PLL-MNPs and ARA-MNP on SH-SY5Y cells is time and dose-dependent; however, ARA-MNPs nanoparticles showed cytotoxicity (Figure 5). These data demonstrate that the homemade particles are less cytotoxic, and a concentration of $10 \mu \mathrm{g} / \mathrm{mL}$ of PLL-MNPs can be considered safe for any biological use (cell viability $>82 \%$ ). Schwann cell cultures of the peripheral nervous system (PNS) revealed dose-response behavior similar to that found in cell line cultures but with a lower $\mathrm{EC}_{25}\left(10.35 \mu \mathrm{g} / \mathrm{mL}, \mathrm{R}^{2}=0.9991\right.$ compared to $20.8 \mu \mathrm{g} /$ $\mathrm{mL}, \mathrm{R}^{2}=0.9992$ PLL-MNPs) (Figure 6). This indicates that PNS cultures are more delicate than the immortalized cell line. A working concentration of $10 \mu \mathrm{g} / \mathrm{mL}$ seems to induce low toxicity in primary cultures as well. Images of nuclear fast red-aluminum sulphate and Prussian blue seem to support these results. The cultures illustrated a good integrity and composition, and PLL-MNPs seem to cluster strongly to cell surface.

These results indicate that PLL-MNPs are good candidates for biocompatible magnetic agents for magneticallydriven cell actuation. In order to evaluate the capacity of PLL-MNPs to magnetize biological entities, cell migration assays were performed using an external constant magnetic field produced by a commercial NdFe-based magnet. The ability of this magnetic source to shepherd magnetized cells towards the region of maximum field density was
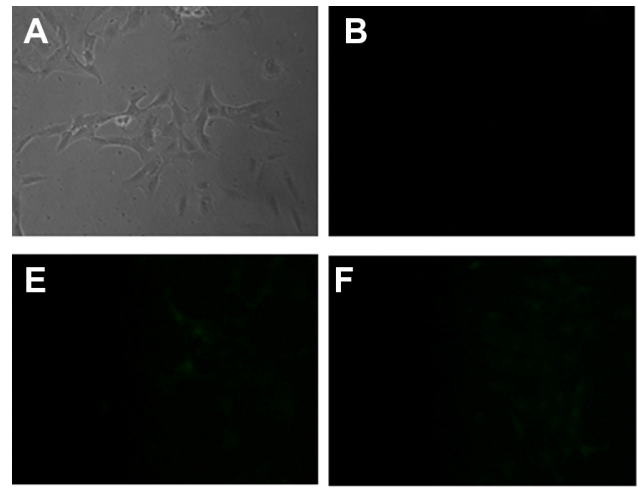
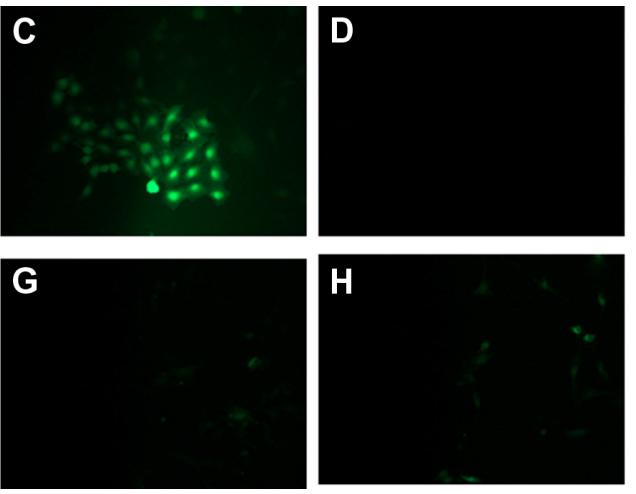

Figure 8 Images showing ROS detection on SH-SY5Y cells treated for 24 hours with increasing concentration of PLL-MNP. (A and B) are the bright field and the fluorescent images, respectively, of the negative control; $(\mathbf{C})$ is the fluorescent image of the positive control (cell treated with TBHP); (D-H) are fluorescent images of cells incubated with I, 5, 10, 20, and $50 \mu \mathrm{g} / \mathrm{mL}$ of PLL-MNPs, respectively.

Abbreviations: PLL-MNP, poly-I-lysine-magnetic nanoparticle; TBHP, tert-butyl hydroperoxide. 


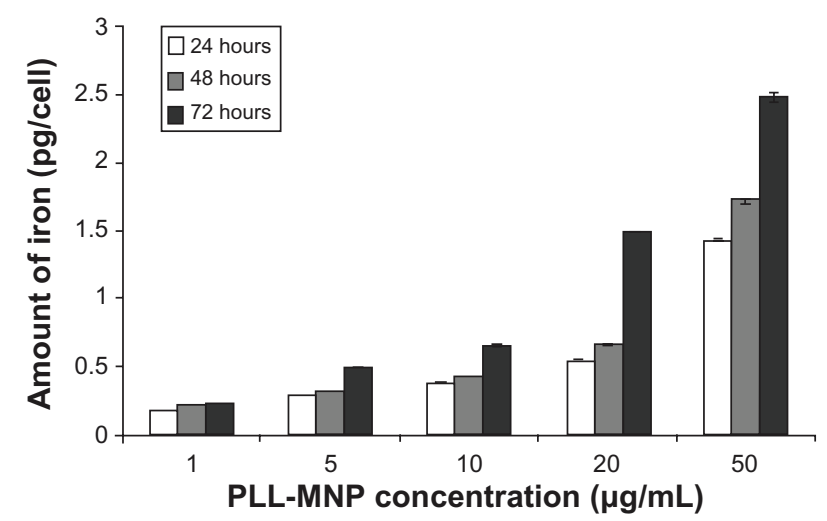

Figure 9 Internal iron content per cell at different times evaluated by Ferrazine method.

Abbreviation: PLL-MNP, poly-I-lysine-magnetic nanoparticle.

performed using PLL-MNPs and, for comparison purposes, similar experiments were performed with commercial ARA-MNPs.

After three days of exposure to the magnetic source, the local cell densities were measured and normalized with respect to the average cell density in the well. As can be seen in panel A of Figure 7, for SH-SH5Y cells, the cell density at different distances from the magnet was essentially constant for the control samples ( $\sim 30$ in AU). On the other hand, both types of poly-lysine coated MNPs reflected the influence of the magnetic forces as a migration of cells towards the magnetic field source. The amount of cells loaded with PLL-MNPs ranged from 10 to $65 \mathrm{AU}$ at a distance of 15 to $5 \mathrm{~mm}$ from the magnet; while commercial poly-lysine coated ARA-MNPs only ranged from 20 to $50 \mathrm{AU}$. Again, the PNS cultures revealed a similar behavior, but the strength of the cell migration was lower (Figure 7B). This is easily explained because the adhesion of primary cells to the substrate is stronger due to the laminin coating, which is a crucial parameter for cell migration. ${ }^{21}$

These results indicate the better performance of PLLMNPs as efficient actuators of magnetically-loaded cells. This finding is in agreement with the mathematical analysis that predicted that a single PLL-MNP exerts a higher magnetic force (of two orders of magnitude) than a single ARAMNP when exposed to the magnetic field generated by the permanent magnet used in this study (Figure 7C).

\section{Intracellular localization of PLL-MNPs and biological effects}

The biological effects of PLL-MNPs were further investigated in the SH-SY5Y cell line. Similar results to the Trypan blue test were achieved by testing the cell doubling time: the concentration of $10 \mu \mathrm{g} / \mathrm{mL}$ of PLL-MNPs was not significantly different from the control (Table 2).

Since the net magnetic force exerted on magneticallyloaded cells increased with the loading of MNPs, this study investigated possible ROS-mediated cytotoxicity due to homemade particles within a wide range of concentrations. The aim was to determine the upper tolerable limit while retaining cell viability and functionality. ${ }^{22}$

As can be seen in Figure 8, increasing the concentration of PLL-MNPs from 1 to $10 \mu \mathrm{g} / \mathrm{mL}$ resulted in a level of ROSinduced toxicity that was comparable to the negative control. The presence of ROS was only detectable for concentrations larger than $20 \mu \mathrm{g} / \mathrm{mL}$, although even with the highest MNP concentration tested $(50 \mu \mathrm{g} / \mathrm{mL})$, the detection of ROS was much lower than the positive control. These data justify the choice of $10 \mu \mathrm{g} / \mathrm{mL}$ as working MNP concentration for safe biological use.
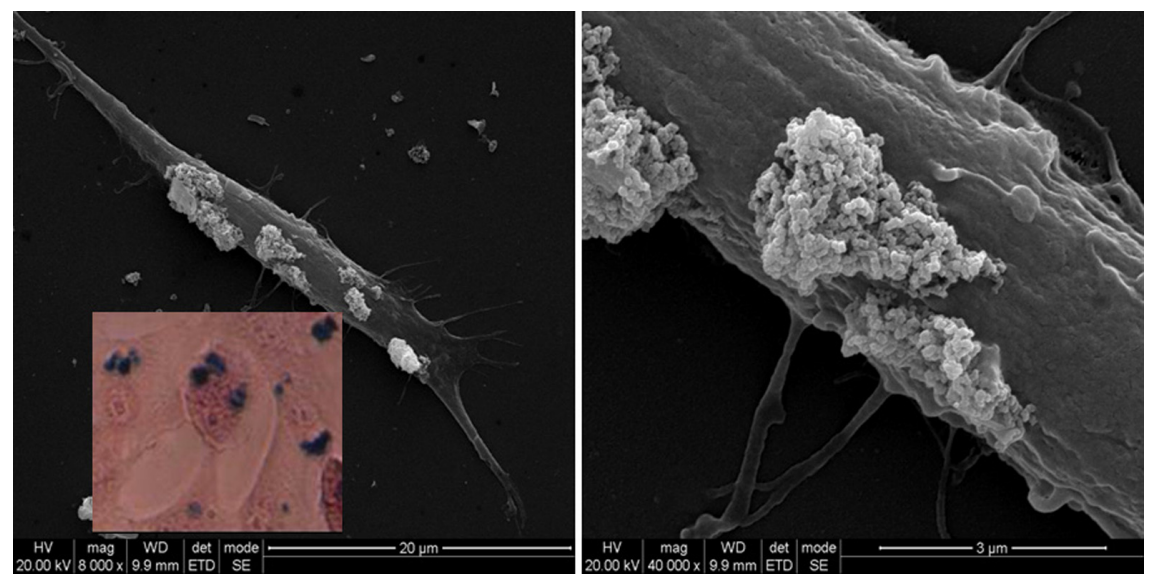

Figure 10 Scanning electron microscopy image of a single SH-SY5Y cell incubated for 24 hours with $10 \mu g / m L$ PLL-MNPs, showing the presence of MNP agglomerates (bright spots) on the cell membrane. Inset: Prussian blue staining on the same culture.

Abbreviations: MNP, magnetic nanoparticle; PLL-MNP, poly-l-lysine-magnetic nanoparticle. 

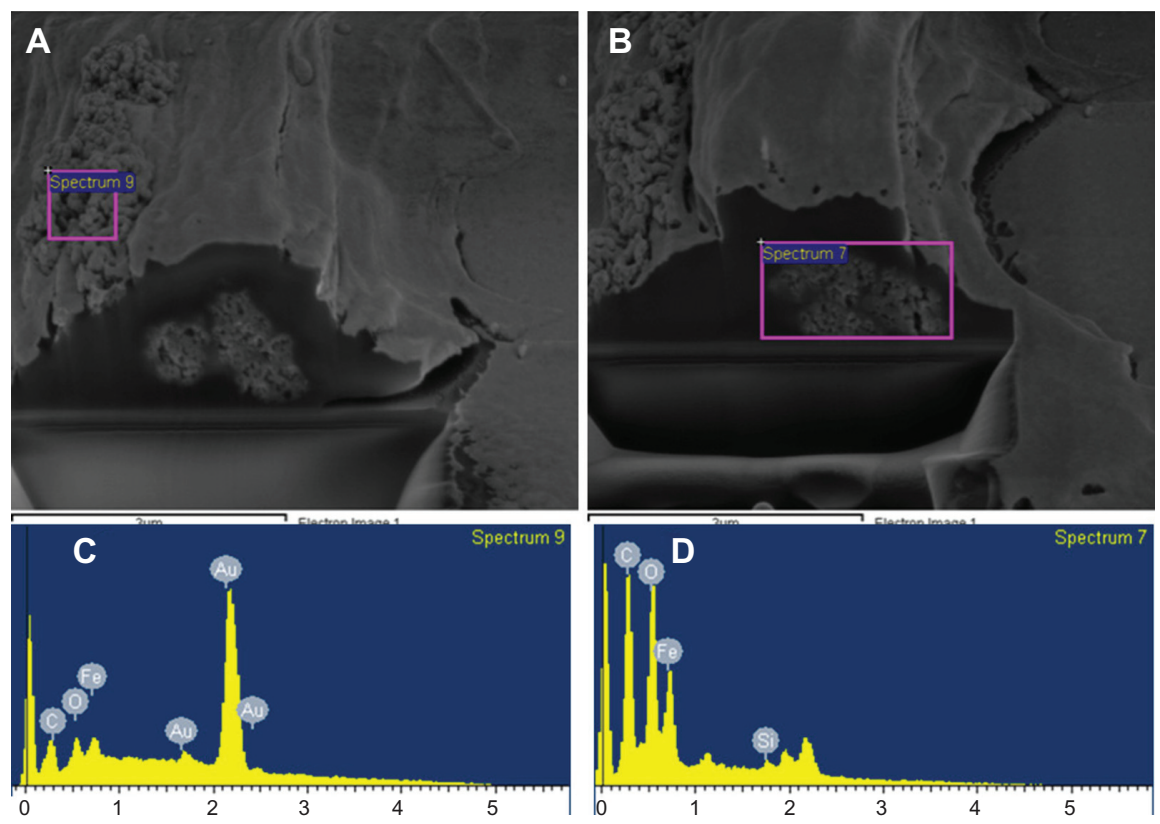

Figure I I Cell viability dual-beam (FIB/SEM) images of SH-SY5Y cells incubated with $5 \mu \mathrm{g} / \mathrm{mL}$ PLL-MNPs for 24 hours. (C and D) are the EDX spectra from the corresponding areas of the (A and $\mathbf{B})$ (pink squares), confirming the presence of MNPs in the cell membrane (A and $\mathbf{C})$ and the intracellular space (B and $\mathbf{D})$.

Abbreviations: FIB, focused ion beam; MNPs, magnetic nanoparticles; PLL-MNPs, poly-l-lysine-magnetic nanoparticles; SEM, scanning electron microscopy.

The intracellular iron content was found to be dose- and time-dependent within the range of times and concentrations tested (Figure 9).

The cellular localization of PLL-MNP after incubating with PLL-MNPs at a concentration of $10 \mu \mathrm{g} / \mathrm{mL}$ at different times was explored using Prussian blue staining and SEM analysis.

SEM images showed that after incubation, a fraction of PLL-MNPs were strongly attached to the cell membrane, forming large clusters ranging from 1 to $5 \mu \mathrm{m}$. In agreement with the SEM images, Prussian blue staining supported the finding that these PLL-MNP clusters were strongly attached to the cell membrane. To further assess the internalization of the PLL-MNPs, single SH-SY5Y were cross-sectioned with FIB and analyzed by SEM after being cultured in the presence of $5 \mu \mathrm{g} / \mathrm{mL}$ of PLL-MNPs for 24 hours. Figure 10 shows the agglomeration of the PLL-MNPs attached to the outside part of the cell membrane, and the agglomerates can be seen in the intracellular space. EDX analysis was performed to identify these structures as PLL-MNPs. The EDX spectra confirmed the presence of PLL-MNPs inside the cells (Figure 11).

\section{Conclusion}

This study provides a protocol for the synthesis of novel $\mathrm{Fe}_{3} \mathrm{O}_{4}$ particles. To improve the interaction at the cellular level a coating of PLL was adsorbed into the negative surface of MNPs. The accumulation of magnetic particles in the cells was facilitated by the PLL-coating of the particle's surface, which was likely due to the resulting surface charge, ${ }^{23}$ as confirmed by the Z-potential data. Furthermore, the results from the SEM and dual-beam microscopy (Figures 10 and 11) demonstrated the effective internalization of the MNPs in large amounts. The final distribution at the cellular level consisted of large agglomerates of MNPs that were attached to the cell membrane and the intracellular space. This tendency for particle agglomeration on cell membranes and intracellularly can be easily explained by the strong dipole-dipole interactions among magnetic particles. Furthermore, the observed agglomerates not only attach to the cell membrane, but extend in a continuous way into the cytoplasm.

The commercial MNPs used in this study for comparison purposes were fluidMAG-ARA. Such particles were submitted to functionalization with PLL in order to compare their resulting properties and biological effects with our homemade PLL-MNPs. Additionally, the two classes of MNPs had similar hydrodynamic radiuses around $200 \mathrm{~nm}$. It is worth mentioning that Kettering et al previously employed ARA-MNPs for magnetic labeling and the heating of tumor cells. ${ }^{20}$

The larger saturation magnetization $\mathrm{M}_{\mathrm{S}}\left(78\right.$ and $49 \mathrm{Am}^{2} /$ $\mathrm{kg}$, for PLL-MNPs and ARA-MNPs, respectively) revealed that our homemade nanoparticles were consistent with the higher efficiency observed in the cell migration experiments, since the magnetic force exerted on a single cell is 
proportional to the magnetic moment of the incorporated MNPs for a given magnetic field value (and its spatial derivative).

In order to avoid the interference of nanoparticles in the common viability tests based on colorimetric reaction and absorbance readings, trypan blue counting tests were carried out following a long incubation time that lasted up to 7 days. $\mathrm{EC}_{25}$ for the SH-SY5Y cells was found to be about $20.8 \mu \mathrm{g} / \mathrm{mL}$ for PLL-MNPs $\left(\mathrm{R}^{2}=0.9992\right)$ and $12 \mu \mathrm{g} / \mathrm{mL}$ for PLL-coated ARA-MNPs $\left(\mathrm{R}^{2}=0.9368\right)$. Based on these results, our particles were less toxic and a concentration of $10 \mu \mathrm{g} / \mathrm{mL}$ could be considered safe for any biological use. In terms of the future in vivo application, experiments with mixed primary cell cultures of the PNS were conducted to get a first impression of their responses to the homemade MNPs. The experimental results confirmed that PLL-MNPs interact strongly with primary cells. Although the concentration of the particles to be used for our scope induced low cytotoxicity $(<25 \%$ ), as expected, the PNS cultures seem to be more sensitive to the PLL-MNPs then the cell line cultures $\left(10.35 \mu \mathrm{g} / \mathrm{mL}, \mathrm{R}^{2}=0.9991\right.$ compared to $20.8 \mu \mathrm{g} / \mathrm{mL}$, $\mathrm{R}^{2}=0.9992$ ). This highlights the importance of taking the higher sensitivity of primary cells of the PNS into account in all future investigations.

Furthermore, the results of the cell migration assay confirm a better capability of PLL-MNP- over PLL-coated fluidMAG-ARA MNPs to magnetize cells. Compared to the commercial particles, our homemade MNPs induced a more pronounced cell migration effect toward the magnetic source. The effect was stronger for the cell line cultures relative to the PNS cultures, due to the higher adhesion of the primary cells to the substrate (laminin-coated wells). Therefore, this study successfully developed novel $\mathrm{Fe}_{3} \mathrm{O}_{4}$ nanoparticles with negligible cytotoxicity and a high capacity to manipulate mammalian cells.

The possibility of shepherding cells toward an energy source is significant in terms of the widespread interest in cell tracking, cell therapies, and tissue engineering. The general aim of this study is to develop novel MNPs for use as functional nanotools to enhance nerve regeneration by exploiting the mechanical forces that act on MNP-neurons to promote axonal elongation/growth. After a nerve is severed, functional reinnervation requires that axons continue to grow until they reach their distal target. In humans, axonal regeneration occurs at a rate of about $1 \mathrm{~mm}$ /day. Our future work will demonstrate that MNPs can be used as novel technologies to facilitate the regeneration of peripheral nerves after injury. The application of a tensile force to a neuron or an axon can stimulate neurite initiation or axon elongation in the desired direction. MNPs can be used to generate these tensile forces and manipulate axons to elongate, overcome inhibitory substrates, and enhance the trophic signaling of axon growth through the functionalization of biological molecules, eg, neural binders and neurotrophic factors.

Although clinical protocols currently use many types of MNPs, the use of iron oxides in the form of MNPs has raised some concerns about toxicity arising from poor water solubility and the nanometer size. The potential adverse effects of iron nanoparticles and measures to reduce these effects require further investigation. ${ }^{24-26}$ Therefore, further tests were performed on our particles to investigate the intracellular localization of PLL-MNP and its biological effects in detail. The typical cell doubling time for untreated cell is 24 hours; the presence of particles in the cell medium increased the replication rate - indicating interference in the cell cycle - at high concentrations, but the concentration of $10 \mu \mathrm{g} / \mathrm{mL}$ had no effect. Cell viability was found to be doseand time-dependent. This suggests that the mechanisms of cytotoxicity can be triggered by the MNP degradation in $\mathrm{Fe}$ ions. ${ }^{27}$ It has been reported that MNPs are normally ingested via endocytosis into phagosomes, which eventually fuse with lysosomes for degradation because of the acid environment. ${ }^{28}$ The products of MNP degradation (Fe ions) are responsible for the production of ROS. However, in this respect, the experimental data indicated that the range of concentration $1-10 \mu \mathrm{g} / \mathrm{mL}$ induced negligible cell toxicity as the amount of intracellular Fe ions was not far from the physiological level and was lower than those resulting from the use of commercial MNPs such as Resovist and Endorem. ${ }^{29}$

The final distribution of large magnetic agglomerates anchored to the SH-SY5Y cells appears to be potentially useful for cellular actuation through external magnetic forces. Our present work represents the first steps on the exploitation of MNPs to enhance the regeneration of injured nerves.

\section{Acknowledgments}

This work was supported by the MARVENE project (MAgnetic nanopaRticles For NerVE RegeNEration Nanosci-E +2008). Partial financial support from the Spanish Ministerio de Ciencia e Innovación (project MICINN MAT2010-19326) is also acknowledged. We are grateful to Carlos Cuestas Ayllon for his valuable advice and help with SEM-EDX analysis.

\section{Disclosure}

The authors report no conflicts of interest in this work. 


\section{References}

1. Gao JH, Gu HW, Xu B. Multifunctional magnetic nanoparticles: design, synthesis, and biomedical applications. Accounts Chem Res. 2009;42:1097-1107.

2. Sun C, Lee JSH, Zhang MQ. Magnetic nanoparticles in MR imaging and drug delivery. Adv Drug Deliv Rev. 2008;60:1252-1265.

3. Veiseh O, Gunn JW, Zhang MQ. Design and fabrication of magnetic nanoparticles for targeted drug delivery and imaging. Adv Drug Deliv Rev. 2010;62:284-304.

4. Goya GF, Grazu V, Ibarra MR. Magnetic nanoparticles for cancer therapy. Curr Nanosci. 2008;4:1-16

5. Gupta AK, Naregalkar RR, Vaidya VD, Gupta M. Recent advances on surface engineering of magnetic iron oxide nanoparticles and their biomedical applications. Nanomedicine (Lond). 2007;2:23-39.

6. Gupta AK, Gupta M. Synthesis and surface engineering of iron oxide nanoparticles for biomedical applications. Biomaterials. 2005;26:3995-4021.

7. Laurent S, Forge D, Port M, et al. Magnetic iron oxide nanoparticles: Synthesis, stabilization, vectorization, physicochemical characterizations, and biological applications. Chem Rev. 2008;108:2064-2110.

8. Misra RDK. Magnetic nanoparticle carrier for targeted drug delivery: perspective, outlook and design. Mater Sci Tech. 2008;24: 1011-1019.

9. McCarthy JR, Kelly KA, Sun EY, Weissleder R. Targeted delivery of multifunctional magnetic nanoparticles. Nanomedicine (Lond). 2007;2:153-167.

10. McCarthy JR, Weissleder R. Multifunctional magnetic nanoparticles for targeted imaging and therapy. Adv Drug Deliv Rev. 2008;60: 1241-1251.

11. Wilhelm C, Gazeau F. Universal cell labelling with anionic magnetic nanoparticles. Biomaterials. 2008;29:3161-3174.

12. Wilson MW, Kerlan RK Jr, Fidelman NA, et al. Hepatocellular carcinoma: Regional therapy with a magnetic targeted carrier bound to doxorubicin in a dual MR imaging/conventional angiography suite initial experience with four patients. Radiology. 2004;230:287-293.

13. Pankhurst QA, Connolly J, Jones SK, Dobson J. Applications of magnetic nanoparticles in biomedicine. J Phys D Appl Phys. 2003;36: R167-R181.

14. Vittorio O, Quaranta P, Raffa V. Magnetic carbon nanotubes: a new tool for shepherding mesenchymal stem cells by magnetic fields. Nanomedicine (Lond). 2011;6:43-54.

15. Wilhelm C, Bal L, Smirnov P, et al. Magnetic control of vascular network formation with magnetically labeled endothelial progenitor cells. Biomaterials. 2007;28:3797-3806.

16. De Silva MN, Almeida MV, Goldberg JL. Developing super-paramagnetic nanoparticles for central nervous system axon regeneration. In: Technical Proceedings of the 2007 NSTI Nanotechnology Conference and Trade Show,Volume 2. 2007 May 20-24; Santa Clara, CA.
17. Vergés MA, Costo R, Roca AG, et al. Uniform and water stable magnetite nanoparticles with diameters around the monodomain-multidomain limit. J Phys D Appl Phys. 2008;41:10.

18. Diaz G, Liu SS, Isola R, Diana A, Falchi AM. Mitochondrial localization of reactive oxygen species by dihydrofluorescein probes. Histochem Cell Biol. 2003;120:319-325.

19. Riemer J, Hoepken HH, Czerwinska H, Robinson SR, Dringen R. Colorimetric ferrozine-based assay for the quantitation of iron in cultured cells. Anal Biochem. 2004;331:370-375.

20. Kettering M, Winter J, Zeisberger M, et al. Magnetic nanoparticles as bimodal tools in magnetically induced labelling and magnetic heating of tumour cells: an in vitro study. Nanotechnology. 2007;18: $175-101$.

21. Raffa V, Vittorio O, Ciofani G, Pensabene V, Cuschieri A. Cell creeping and controlled migration by magnetic carbon nanotubes. Nanoscale Res Lett. 2009;5:257-262.

22. Emerit J, Beaumont C, Trivin F. Iron metabolism, free radicals, and oxidative injury. Biomed Pharmacother. 2001;55:333-339.

23. Babic M, Horák D, Trchová M, et al. Poly(L-lysine)-modified iron oxide nanoparticles for stem cell labeling. Bioconjug Chem. 2008;19:740-750

24. Park EJ, Kim H, Kim Y, Yi J, Choi K, Park K. Inflammatory responses may be induced by a single intratracheal instillation of iron nanoparticles in mice. Toxicology. 2010;275(1-3):65-71.

25. Feng JH, Liu HL, Zhang LM, Bhakoo K, Lu LH. An insight into the metabolic responses of ultra-small superparamagnetic particles of iron oxide using metabonomic analysis of biofluids. Nanotechnology. 2010;21:395101.

26. Soenen SJ, Brisson AR, De Cuyper M. Addressing the problem of cationic lipid-mediated toxicity: The magnetoliposome model. Biomaterials. 2009;30:3691-3701.

27. Bergamini CM, Gambetti S, Dondi A, Cervellati C. Oxygen, reactive oxygen species and tissue damage. Curr Pharm Des. 2004;10:1611-1626.

28. Schwalbe M, Jorke C, Buske N, Hoffken K, Pachmann K, Clement JH. Selective reduction of the interaction of magnetic nanoparticles with leukocytes and tumor cells by human plasma. J Magn Magn Mater. 2005;293:433-437.

29. Soenen SJ, Nuytten N, De Meyer SF, De Smedt SC, De Cuyper M. High intracellular iron oxide nanoparticle concentrations affect cellular cytoskeleton and focal adhesion kinase-mediated signaling. Small. 2010;6:832-842.
International Journal of Nanomedicine

\section{Publish your work in this journal}

The International Journal of Nanomedicine is an international, peerreviewed journal focusing on the application of nanotechnology in diagnostics, therapeutics, and drug delivery systems throughout the biomedical field. This journal is indexed on PubMed Central, MedLine, CAS, SciSearch $\AA$, Current Contents ${ } /$ Clinical Medicine,

\section{Dovepress}

Journal Citation Reports/Science Edition, EMBase, Scopus and the Elsevier Bibliographic databases. The manuscript management system is completely online and includes a very quick and fair peer-review system, which is all easy to use. Visit http://www.dovepress.com/ testimonials.php to read real quotes from published authors. 